\title{
OD ARCHEOLOGICKÉHO NÁLEZU KE SBÍRKOVÉMU PŘEDMĚTU

\section{IVANA BLAŽKOVÁ}

\section{ABSTRAKT/ABSTRACT:}

Studie přináší vhled do dvou příbuzných oborů - archeologie a muzeologie. Aplikují se v ní poznatky archeologů na muzejní praxi. Je zde předložen výsledek dotazníkového šetření zaměřeného na práci archeologů ze sbírkotvorných a nesbírkotvorných institucí, jejich postup práce nakládání s archeologickými nálezy od jejich vyjmutí in situ až po uložení in fondo.

\section{From archaeological find to mu- seum object}

The study offers an insight into two related disciplines - archaeology and museology. Archaeological knowledge is being applied here to the museum practice. The study presents the outcome of a questionnaire survey focused on the work of archaeologists from collection-making and noncollecting institutions, and their method of operation in handling of archaeological finds from their recovery on site to their deposition in museum collections.

\section{KLÍČOVÁ SLOVA/KEYWORDS:}

archeologické nálezy - archeologie muzejnictví - speciální muzeologie památková péče

archaeological finds - archaeology museums - special museologies - preservation of historical monuments

\section{Východiska a cíle}

Předkládaný text vychází z magisterské diplomové práce $\mathrm{z}$ oboru mu- zeologie na Filozofické fakultě Masarykovy univerzity ${ }^{1}$ a tematicky navazuje na předchozí bakalářskou práci. ${ }^{2}$ Jedná se o př́spěvek k tématu speciální muzeologie formou aplikování poznatků archeologů na muzejní podmínky a praxi. Tento pojem a problematika, které uvedl do odborné literatury v polovině minulého století Jiří Neustupný, nejsou v současné době příliš zpracovávány a zdají se být nedostatečně hodnoceny vzhledem $\mathrm{k}$ objemu archeologických nálezů a jeho vlivu na muzea a sbírky. Díla Jiřího Neustupného Otázky dnešního muzejnictvi ${ }^{3}$ a Muzeum a věda $a^{4}$ spolu s publikací Muzeologie a archeologie ${ }^{5}$ Zbyňka Zbyslava Stránského jsou stále nepřekonaná.

Cílem je navržení kvalitativních změn v nakládání $s$ archeologickými sbírkami/nálezy v našich

\footnotetext{
1 BLAŽKOVÁ, Ivana. Od archeologického nálezu ke sbírkovému předmětu: prüzkum péče o archeologické nálezy ve sbírkotvorných i nesbírkotvorných institucích $v$ České republice a $v$ sousedních státech. Brno: Masarykova univerzita, Filozofická fakulta Masarykovy univerzity, Ústav archeologie a muze ologie, 2017. Magisterská diplomová práce. $129 \mathrm{~s}$. Vedoucí práce PhDr. Irena Loskotová, Ph.D.
}

2 BLAŽKOVÁ, Ivana. Archeologické sbírky v památ kové péči na př́kladu Národního památkového ústa$v u$, územního odborného pracoviště v hlavním městě Praze. Brno: Masarykova univerzita, Filozofická fakulta Masarykovy univerzity, Ústav archeologie a muzeologie, 2015. 78 s. Bakalářská diplomová práce. Vedoucí práce PhDr. Irena Loskotová, Ph.D.

3 NEUSTUPNÝ, Jiří. Otázky dnešního musejnictví: př́spěvky k obecné a speciální museologii. Praha:

Orbis, 1950. 207 s.

4 NEUSTUPNÝ, Jiří. Muzeum a věda. Praha:

Kabinet muzejní a vlastivědné práce při Národním muzeu v Praze, 1968. 168 s.

5 STRÁNSKÝ, Zbyněk Zbyslav. Archeologie a muzeologie. 1. vyd. Brno: Masarykova univerzita, 2005. 315 s. sbírkotvorných ${ }^{6}$ i nesbírkotvorných institucích, jež by mělo být předmětem následné oborové diskuze a vyústit pak v obecně akceptovatelné podněty ke zlepšení stávající situace. Prvním krokem k dosažení tohoto cíle je zmapování současného stavu problematiky, což proběhlo formou dotazníkového šetření v institucích obojího typu, které se zpracováním a ochranou archeologických nálezů zabývají.

Pro získání výchozích dat potřebných $\mathrm{k}$ analýze stávajícího stavu bylo zvoleno dotazníkové šetření, které se pro podobné případy jeví jako optimální z hlediska aktuálnosti a dostupnosti informací. Prostřednictvím dotazníku byly osloveny instituce, jež získaly př́slušné oprávnění od Ministerstva kultury ČR a uzavřely s Akademií věd ČR Dohodu o provádění archeologických výzkumů.

Elektronickou poštou bylo obesláno 99 z celkového počtu 106 institucí. ${ }^{7} \mathrm{Z}$ těchto 99 dotazovaných reagovalo 50 institucí s 53 vyplněnými dotazníky, poněvadž ve dvou institucích odpovědělo více archeologů. Výsledky šetření vy-

6 Ke sbírkotvorným institucím náleží muzea, at již zřízená státem nebo kraji, či obcemi, a některá územní odborná pracoviště Národního památkového ústavu.

7 Šest institucí nebylo kontaktováno bud' z důvo du nevykonávání archeologických výzkumů, neuzavření platné dohody s Akademií věd ČR, nebo pro nedostupnost kontaktu, sedmou institucí byl Národní památkový ústav, jehož aktivita byla podrobně popsána již ve výše zmiňované autorčině bakalářské práci (BLAŽKOVÁ, Ivana. Archeologické sbírky $v$ památkové péči na príkladu Národního památkového ústavu, územního odborného pracoviště $v$ hlavním městě Praze. Brno: Masarykova univerzita, Filozofická fakulta Masarykovy univerzity, Ústav archeologie a muzeologie, 2015, s. 43-44. Bakalářská diplomová práce. Vedoucí práce $\mathrm{PhDr}$. Irena Loskotová, Ph.D.). 
cházejí z odpovědí od jednotlivých respondentů, nikoli celých institucí, což se ukázalo být racionálním řešením, nebot i $\mathrm{v}$ rámci samotné instituce se odpovědi jednotlivců někdy diametrálně lišily. Vzhledem $\mathrm{k}$ tomu, že procento navrácených a vyplněných dotazníků bylo vyšší jak $40 \%$, byly považovány jeho výsledky za relevantní. Pro ilustraci byly výsledné poznatky z českých a moravských institucí obohaceny o prríspěvek z Polska, Francie, Řecka a Rakouska.

\section{Struktura dotazníku}

Dotazník byl strukturován do deseti základních tematických okruhů, které se dále členily upřesňujícími otázkami a podotázkami. Posloupnost jednotlivých dotazů korespondovala s postupem archeologů při získávání archeologických nálezů od zjištění předmětu in situ, exkavace, primární selekce, dokumentace, evidence, konzervace až po uložení in fondo ve sbírkotvorné instituci - muzeu - a jeho následné prezentaci, zpřístupnění badatelům. Vzhledem $\mathrm{k}$ tomu, že instituce s oprávněním vykonávat archeologické výzkumy jsou dvojího charakteru, a to sbírkotvorné a nesbírkotvorné, závěrečný dotaz byl zaměřen na jejich vzájemnou kooperaci. Třebaže ve stavbě dotazníku převažovaly otázky uzavřené, byl zde dán prostor respondentům i pro širší vyjádření se k dotazované problematice a někteří ho využili. Jedinou cíleně otevřenou otázkou byla pouze poslední, kde respondenti měli reagovat na interinstitucionální spolupráci.

\section{Selekce a archeologický nález}

První okruh otázek se týkal vymezení pojmů „selekce“ a ,archeologický nález", co za něj respondenti považují, jaká jsou jejich kritéria př̀i výběru předmětů v terénu a zda respondenti nějaká kritéria uplatňují. ${ }^{8}$

\section{Z celkového vyhodnocení dotazu} vyplynulo, že za archeologický nález ${ }^{9}$ jsou považovány předměty, které dokládají lidskou existenci na zkoumaném místě (autentičtí svědkové skutečnosti). I neopracovaný kámen, pokud je v kontextu $\mathrm{s}$ př́ślušnou nálezovou situací, nebo paleobotanické vzorky z odpadní jímky mohou být archeologickými nálezy, nebot jsou důkazem lidské činnosti na daném místě. Naproti tomu mamutí kel, vylovený např́íklad z řečiště (bez jasné datace

8 Obecně lze archeologické nálezy dělit do dvou základních skupin:

1) movité

2) nemovité

Movité nálezy následně zařadit do dalších kategorií:

a) artefakty - veškeré předměty vzniklé lidskou činností, dělitelné dle materiálu, ze kterého byly zhotoveny

b) ekofakty - zvířecí kosti, výrobní odpad (struska)

c) lidské ostatky

d) naturfakty (někdy označované i jako ekofak-

ty) - enviromentální vzorky, mušle

Nemovité nálezy děleny podle důvodové zprávy $\mathrm{k}$ památkovému zákonu:

a) „zbytky opevněných i neopevněných sídlišt', které se zachovaly na povrchu nebo pod povrchem zemé, jako např. hradiště, tvrziště, kultovní místa, valy, príkopy, brány, jakož i pozůstatky chat, ohništ', studní, zásobních i odpadních jam, výrobních a hospodářských objektů, cest, polí (plužin), komunikací apod.,

b) hroby a pohřebiště žárové nebo kostrové, uchované na povrchu země (mohyly) nebo pod zemí (hroby) apod.,

c) pozůstatky získávání a zpracování surovin, napr̆. stará horní díla jako doly, lomy, sejpy, odvaly, haldy apod. (tj. zbytky materiálu po rýžování zlata),

d) jeskyně jako sídliště člověka,

e) staré kresby a nápisy na skalách nebo kamenech" (KRUŠINOVÁ, Lenka a Jiří VARHANÍK. Archeologické výzkumy a nálezy: výukový materiál $k$ předmètu AEB_34 Právní rámec záchranného archeologického výzkumu. Brno: Ústav archeologie a muzeologie Masarykovy univerzity [online]. [cit. 2017-04-14]. Dostupný z www: <https://is.muni.cz/el/1421/ podzim2013/AEB_34/Cast_III._zak.c.20-1987_Sb. doc $>$; systematiku archeologických pramenů $\mathrm{z}$ archeologického pohledu lze nalézt $\mathrm{v}$ pracích Evžena Neustupného: NEUSTUPNÝ, Evžen. Metoda archeologie. Plzeň: Vydavatelství a nakladatelství Aleš Čeněk, 2007, s. 27-42; NEUSTUPNÝ, Evžen. Vymezení archeologie. In Archeologie pravěkých Čech/1: pravěký svět a jeho poznání. Praha: Archeo logický ústav AV ČR, Praha, 2007, s. 11-22).

9 Ustanovení § 21 odst. 1 zákona č. 20/1987 Sb., o státní památkové péči vymezuje archeologický nález: jako „věc (soubor věcí), která je dokladem nebo pozůstatkem života člověka a jeho činnosti od počátku jeho vývoje do novověku a zachovala se zpravidla pod zemí"(Česká republika. Zákon č. 20/1987 Sb., o státní památkové péči, ve znění pozdějších změn podle právního stavu [online]. [cit. 2017-06-26]. Dostupný z www: <https://www. zakonyprolidi.cz/cs/1987-20>). a s žádným prokazatelným vztahem k lidskému osídlení) jako archeologický nález vnímán není. Z větší množiny naturfaktů, tak vystupuje menší jasně definovaná skupina, která je považována za archeologický nález. V tomto bodě panovala shoda i mezi zahraničními respondenty.

Na rozdíl od termínu ,archeologický nález", jehož definice se opírá o literu zákona, je vymezení pojmu „selekce“ poněkud složitější a pro jeho výklad je třeba využít autorit teoretické muzeologie. Ta rozeznává dva typy selekce, a to pasivní a aktivní. ${ }^{10}$ Pasivní selekce se týká předmětů, které dokumentují věci minulé, jež se zachovaly z minulosti. Hrozí zde ale omezení výpovědní hodnoty, nebezpečí zkreslení, nebot chybí průvodní dokumentace, a proto není často zjistitelné, jak předmět fungoval a k čemu sloužil. Mưže se rovněž stát, že se nezachová vždy to, co je podstatné a nejhodnotnější a není možnost výběru. Čas „vybírá“ za nás a my pouze pasivně přijímáme. Aktivní selekce se provádí při dokumentaci současnosti, to znamená u zachycení přítomnosti nebo nedávné minulosti. Jejím prostřednictvím lze vytvořit odkaz pro budoucí generace. ${ }^{11}$ Mezi výhody patří možnost vybrat to nejautentičtější, vytěžit kvalitní průvodní dokumentaci a zachytit na vhodných médiích i ty jevy, které se věcně nefixují

\footnotetext{
10 Teorií selekce se zabývala a zabývá řada předních muzeologů, například Josef Beneš, Věra Schubertová, Zbyněk Zbyslav Stránský, Friedrich Waidacher, Jiří Žalman. Předmětu teoretická muzeologie u nás v současné době věnují pozornost Jan Dolák a Václav Rutar. Muzejní selekce byla námětem diplomové práce Dmitrije Círa. (viz CÍR, Dimitrij. Teorie muzejní selekce. Masarykova univerzita v Brně, Filozofická fakulta Masarykovy univerzity, Ústav archeologie a muzeologie, 2006. 72 s. Diplomová práce. Vedoucí práce Mgr. Pavel Holman). V archeologii se namísto pojmu pasivní selekce pracuje termínem „teorie transformací“ (NEUSTUPNYY, Evžen. Metoda archeologie. Plzeň: Vydavatelství a nakladatelství Aleš Čeněk, 2007, s. 46-75).

11 Takovým př́kladem je realizovaný projekt Evropy SAMDOK 1, který sjednotil muzea ve Švédsku, vznikl v roce 1977.
} 
(hudba, divadlo). ${ }^{12}$ I tento typ selekce má své nevýhody, $\mathrm{k}$ těm zásadním patř́i čas, protože až ten ukáže, zda byl předmět vybrán správně aktivní selekce má morální význam i přesah. ${ }^{13}$

Teoretikové z oboru muzeologie považují za základní kritérium pro selekci poznání a vyhodnocení „potenciální muzeality" zkoumaného objektu. Z. Z. Stránský v souvislosti s tímto fenoménem hovoří o dvou fázích muzealizačního procesu určení „objektu“ a identifikaci „potenciální muzeálie“ ${ }^{14}$ Pojem „potenciální muzealita“ zmiňuje též ve své práci Věra Schubertová, která tento termín dává do vzájemného vztahu s "prvním dojmem“ v primárním hodnocení předmětu muzealizace. Následujícím stupněm ve struktuře zjištování muzeality a výběru muzeálie je proces poznání, kdy se na zjištování muzeality podílejí vědní obory angažované v muzeu (v tomto případě archeologové), ale objekt nosí stále atribut potenciální muzeality. Třetí a finální fází je sekundární hodnocení, v jehož rámci na základě získaných poznatků muzejník provede zhodnocení předmětu jakožto muzeálie a muzealita se zaktualizuje. ${ }^{15} \mathrm{Z}$ po-

12 Dle Z. Z. Stránského se v tomto případě nejedná o autentickou předmětnou dokumentaci, ale o primární dokumentaci (pokud je záznam tzv. live; STRÁNSKÝ, Zbyněk Zbyslav. Úvod do studia muzeologie. 2. rozšír. vyd. Brno: Masarykova univerzita, 2000, s. 42)

13 DOLÁK, Jan. K teorii sbírkotvorné činnosti muzeí: některé problémy muzejní selekce. In Teorie a praxe vybraných muzejních činností. 1. vyd. Brno: Technické muzeum v Brně, 2005, s. 4-11; Holman, Pavel. Úvod do muzeologie. In Základy muzejní pedagogiky: studijní texty. Brno: Moravské zemské muzeum Brno, 2014, s. 4-17; STRÁNSKÝ, Zbyněk Zbyslav. Úvod do studia muzeologie. 2. rozšír. vyd. Brno: Masarykova univerzita, 2000, s. 41-42; STRÁNSKÝ, Zbyněk Zbyslav. Archeologie a muzeologie. 1. vyd. Brno: Masarykova univerzita, 2005, s. 124.

14 STRÁNSKÝ, Zbyněk Zbyslav. Úvod do studia muzeologie. 2. rozšír. vyd. Brno: Masarykova uni verzita, 2000, s. 40.

15 SCHUBERTOVÁ, Věra. K aktuálním otázkám teorie muzejní selekce. Muzeologické sešity, 1979, 7, s. 38; RUTAR, Václav. Geneze pojmů muzeálie, muzealita a muzealizace na stránkách Muzeologických sešitů v letech 1969-1986 [online]. Museologica Brunensia, 2012, roč. 1, č. 1 (Podzim 2012), s. 10 [cit.2017-06-06]. Dostupný z www: <http:// hdl.handle.net/11222.digilib/131349>. hledu Josefa Beneše se při výběru předmětu musí brát v úvahu tři aspekty, a to, zda se jedná o kulturní statek v obecné poloze, původní pramen vědeckého poznání, nebo prostředek vizuální komunikace plnící výchovně vzdělávací funkci. ${ }^{16}$

Často se jako příklad pasivní selekce uvádějí nálezy z archeologických výzkumů, ale je tomu skutečně tak? Archeolog pomocí zjištěných předmětů hodnotí (vyhodnocuje) nálezovou situaci (struska - vrstva propálené hlíny - pec). Struska je autentickým svědkem metalurgické činnosti v lokalitě, keramický střep datuje vrstvu. Zde se nabízí otázka: je vyjímání předmětů z vrstev aktivní či pasivní selekce? Zde zřejmě jednoznačně odpovědět nelze. V případě archeologických nálezů se jedná o oba typy selekce. Zjednodušeně to lze chápat tak, že výsledkem pasivní selekce je soubor dochovaných předmětů a jejich zařazení do sbírkového fondu je selekcí aktivní. Jaká však jsou kritéria pro selekci nálezů? Shoduje se teorie s praxí?

Jaký je postoj k selekci předmětů v rámci archeologického výzkumu, jaká kritéria uplatňují archeologové? Provádějí selekci a kdy?

K fenoménu selekce přistupovaly ve svých odpovědích oba typy institucí různorodě. Nejčastěji, a to se týkalo i zahraničních respondentů, se provádí selekce předmětů ještě v průběhu archeologického výzkumu, a jejím kritériem bývají na prvním místě nálezové okolnosti, kdy předmět jako primární dokument přispívá $\mathrm{k}$ interpretaci nálezové situace. Dalším faktorem pro možnou selekci je pak sama vypovídací schopnost předmětu. Nadpoloviční většina dotazovaných také realizuje výběr nálezů

\footnotetext{
16 BENES, Josef. Muzeum a sbírky. Praha: Ústav pro informace a ř́izení v kultuře, 1977, s. 95; DOLÁK, Jan. K teorii sbírkotvorné činnosti muzeí: některé problémy muzejní selekce. In Teorie a praxe vybraných muzejních činností. 1. vyd. Brno: Technické muzeum v Brně, 2005, s. 4-11.
}

v rámci procesu mytí, konzervace či restaurování. U nesbírkotvorných institucí se objevila jako kritérium selekce i finanční náročnost konzervace a restaurování nálezu (29 \% respondentů v dané skupině). V případě sbírkotvorných institucí bylo toto kritérium až na výjimky nepodstatné (8\%). Může to být tím, že muzea provádějí konzervování a restaurování nálezů v rámci vlastního pracoviště? Podíváme-li se na tuto otázku z hlediska vyhodnocení okruhu týkajícího se konzervování a restaurování, zjistíme, že sbírkotvorné instituce realizují tyto činnosti u všech dotazovaných komodit, kromě předmětů $\mathrm{z}$ organických materiálůo, z větší části sami. Naproti tomu nesbírkotvorné instituce dodavatelských služeb více využívají u konzervování a restaurování skla, rovným podílem jsou tyto činnosti zastoupeny u organických materiálů a většinou vlastními silami jsou konzervovány nálezy z kovi̊ a keramiky.

Nejméně dotazovaných jako kritérium selekce označilo možnost potenciálního využití nálezu pro dokumentaci současnosti. V tomto případě se selekce provádí nejefektivněji. Nálezy z recentního období bud' procházejí úzkým výběrem, anebo se „neberou“ vůbec. Pro muzeologa může být zarážející obtížné a nejasné chápání pojmu „dokumentace současnosti“ v archeologické obci, které vyplynulo již z konzultací při formulování dotazníku. V současné době, kdy převažují archeologické výzkumy záchranné povahy, by mělo být prioritou z každé zkoumané lokality zachránit vše a vytěžit maximum informací, at se jedná i o předměty z 20. století. Jako možné řešení se nabízí zakotvit stáří předmětu, chápaného jako archeologický nález, do legislativy.

V některých institucích k selekci vůbec nedochází, případně kritéria daná nemají a výběr předmětů záleží spíše na posouzení a znalostech 
odborného pracovníka, či na postupu degradace předmětu. ${ }^{17}$

\section{Dokumentace}

Separováním archeologického nálezu z jeho primárního prostředí se nevratně narušuje původní kontext. Je třeba snížit míru destrukce na minimum, a toho lze dosáhnout jedině kvalitní dokumentací a evidencí jak nálezové situace, tak nálezu samotného. $\mathrm{Z}$ pohledu muzeologa dokumentace zvyšuje vypovídací hodnotu předmětu, jeho muzealitu. ${ }^{18}$ Nedílnou součástí dokumentace je i základní terénní evidence. Př̀i terénní fázi archeologického výzkumu jsou používány různé systémy předběžné evidence nálezů, které se projevují variantním číslováním jednotlivých nálezů či jejich skupin.

Každý archeolog má svůj specifický způsob terénní evidence nálezů. Dotazovaní měli na výběr ze tři základních hledisek (časového,

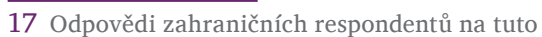
otázku nebyly jednotné, většinou zahrnovaly více možností (kompletnost nálezu, datování nálezu, nálezové okolnosti, možnosti depozitárního uložení nálezu).

18 Z. Z. Stránský nazývá tuto dokumentaci „prů vodní“. Vytváří se v první fázi selekce, kdy nález má ještě charakter potenciální muzeálie. Zároveň se tvoří i tzv. sekundární dokumentace, která má povahu nálezové zprávy, konzervátorsko-restaurátoské zprávy, či přírodovědných analýz. Potenciální muzeálie, průvodní a sekundární dokumentace tvoří celek, který je dále vyhodnocován v tezaurační fázi muzealizačního procesu (STRÁNSKŶ, Zbyněk Zbyslav. Úvod do studia muzeologie. 2. rozšír. vyd. Brno: Masarykova univerzita, 2000, s. 41). Podle J. Beneše se pod pojmem „muzejní dokumentace“ rozumí „dokladování skutečnosti autentiky, jejichž role $v$ pưvodním prostředí musí být ovšem doložena průvodní dokumentací, pořizovanou záměrně při jejich vyjímání z původní skutečnosti. Jde o hodnověrnou fixaci vzniku, ale především o jejich fungování $v$ pưvodních podmínkách s časovým vymezením i zařazením do sociální stratigrafie“. Dokumentace může mít povahu psaného, kresleného, fotografovaného, filmového, zvukového záznamu nebo být jejich kombinací (BENEŠ, Josef. Základy muzeologie. 1. vyd. Opava: Open Education \& Sciencies pro Ústav historie a muzeologie FPF SU, 1997, s. 39). Rakouský muzeolog Friedrich Waidacher rozlišuje dva stupně muzejní dokumentace: primární dokumentaci, kterou vyjadřuje samotný předmět, a proto je autentická, pưvodní a bezprostřední, doplněná doprovodnou dokumentací a sekundární dokumentaci zahrnující všechny záznamy včetně nového muzeálního kontextu předmětu (WAIDACHER, Friedrich. Príručka všeobecnej muzeológie. 1. vyd. Bratislava: Slovenské národné múzeum, 1999, s. 117). posloupnosti a stratigrafického), která archeolog při terénní evidenci zohledňuje. Dủležitou informací byly i formy záznamů předběžné evidence, rozdělené na dvě hlavní, analogovou a digitální, které byly ještě dále konkretizovány. Téměř tři čtvrtiny dotazovaných nejčastěji při dokumentaci a evidenci nálezů braly v úvahu časové hledisko, kdy je evidován soubor nálezů vyzdvižený $\mathrm{z}$ určité stratigrafické jednotky v krátkém časovém úseku (zpravidla za 1 den). Bezmála všichni respondenti preferovali $v$ terénu analogovou podobu evidence nálezů, lišili se pouze ve formě vytvořeného záznamu. Zástupci sbírkotvorných institucí $\mathrm{z}$ analogové formy záznamu evidence nálezů dávají přednost popisu jednotlivých sáčků s identifikací místa odebrání nálezu bez vedení celkového soupisu sáčků. Nesbírkotvorné instituce více využívají soupis sáčků s nálezy na jednotlivých očíslovaných listech tzv. terénního záznamníku.

Digitální formou doplňuje analogové záznamy $77 \%$ všech institucí. V celkovém součtu se více využívá pro soupis nálezů prostředí MS Office Excel nebo MS Office Word než databáze v prostředí MS Office Access. Digitální forma záznamu předběžné evidence se $\mathrm{v}$ terénu běžně nepoužívá, pouze $\mathrm{v}$ rámci zpracování výzkumu mimo terén. Všichni čtyři zahraniční respondenti používají analogovou formu záznamu, ale do digitální převádějí pouze tři, nebot zástupce z Polska se přiklání výhradně $\mathrm{k}$ analogovému způsobu záznamu.

Po základním ošetření nálezů následuje označení jednotlivých předmětů inventárními čísly bud' na předměty samé, nebo na jejich obaly. Předměty vytěžené archeology z nesbírkotvorných institucí čeká po zpracování nálezové zprávy o archeologickém výzkumu uložení v dočasném depozitáři a následný přesun do prríslušného muzea podle § 23a odst. 3 zákona č. 20/1987
Sb., o státní památkové péči. ${ }^{19}$ Pro instituce provádějící záchranný archeologický výzkum je povinným výstupem $\mathrm{z}$ výzkumu nálezová zpráva. Základní informace musí být uvedeny i v hlášení o ukončení archeologického výzkumu v prostředí Archeologická mapa ČR (donedávna Zpráva o archeologické akci).

Pravidla evidence archeologických nálezů jsou popsána v Pokynech ke zhotovení nálezové zprávy, které jsou ke stažení na webových stránkách Archeologického ústavu AV ČR, Praha, v. v. i. ${ }^{20} \mathrm{Z}$ toho je evidentní, že pro detailnější práci s nálezy, včetně evidence, není autor nálezové zprávy nijak veden direktivně a je pouze na jeho uvážení, jak podrobně se chce movitými nálezy zaobírat. Tím se pomyslné nůžky velmi rozevírají. Někde jsou dána pevnější pravidla institucí, někde ne. Samožrejmě každý výzkum je specifický, charakter místa, uloženin i výzkumu ovlivňuje vypovídací možnosti movitých nálezů, a tím i smysluplnost konkrétních úkonů při zpracování. Nelze však nevyslovit myšlenku, že klíčovým faktorem určité rezignace na podrobnější studium a evidenci, která navíc není povinná, jsou i ekonomické tlaky. Jakékoliv zlevnění výzkumu dává konkurenční výhodu při získání „zakázky“, čímž v poslední době bohužel archeologické výzkumy jsou především.

Způsob označení nálezů, průběh jejich evidence a případná sekundární selekce, byly předmětem následujícího okruhu otázek. Téměř tři čtvrtiny dotazovaných evidují všechny nálezy (podobně je tomu

19 Česká republika. Zákon č. 20/1987 Sb. o státní památkové péči, ve znění pozdějších změn podle právního stavu [online]. [cit. 2017-06-26]. Dostupný z www: < https://www.zakonyprolidi. cz/cs/1987-20>

20 Jediný normativní pokyn pro vedení evidence je zmíněn na stránkách ARÚ Pokyny ke zhotovení nálezové zprávy. Archeologický ústav AV ČR, Praha [online]. [aktualizováno 2015-04-12]. [cit. 2017-09-18]. Dostupný z www: <http://www.aruo.cas. $\mathrm{cz} /$ ?cat $=647>$. 
i u zahraničních respondentů). Dotazovaní také zmiňují enviromentální vzorky, vzorky hornin či amorfní zlomky železa, kostí, dřev, které bud' pouze uchovávají a neevidují, nebo je evidují v pomocné evidenci z důvodu snazšího odpisu. U všech institucí ve způsobu aplikace označení převažuje zápis evidenčního (někde přírůstkového čísla) přímo na předmět před označením obalu, ve kterém se předmět nachází. Čárový kód se zatím příliš neujal, i když v některé z institucí již pokusy proběhly. Všichni dotazovaní dávají přednost číselným znakům, jedna instituce používá kombinaci písmen a číslic.

Postup evidence předmětů (budoucích muzeálií) je u sbírkotvorných institucí rízen tzv. muzejním zákonem 122/2000 Sb. Muzejní archeologové tudíž v souladu s tímto zákonem provádějí dvoustupňovou evidenci nálezů, což se archeologů nesbírkotvorných institucí netýká. Po příchodu do muzea se $\mathrm{z}$ archeologických nálezů stávají potenciální sbírkové předměty, které podléhají tezauračnímu postupu dle zákona č. 122/2000 Sb., o ochraně sbírek muzejní povahy a o změně některých dalších zákonů. Nejprve je třeba získanému archeologickému fondu přidělit novou identifikaci (nové číslo), ${ }^{21}$ a to podle prvního stupně muzejní evidence, kterou je chronologická evidence př́růstkử ${ }^{22}$ (předmět získá přírůstkové číslo a stává se sbírkovým předmětem). Přírůstkové číslo se skládá z pořadového čísla sbírkového předmětu

\footnotetext{
21 Jedná se o kvalitativně odlišnou identifikaci, původní číslo se neztrácí a lze jej použít následne v rámci systematické evidence.

22 Zápis obsahuje záznamy uvedené v § 9, odst. 1 zákona 122/2000 (Česká republika. Zákon č. 122/2000 Sb. ze dne 7 . dubna 2000 o ochraně sbírek muzejní povahy a o změně některých dalších zákonů, s platností a účinností od 12. 5. 2000 In Sbírka zákonů České republiky, částka 36 [online]. Aktuální znění 2017-07-01 [cit. 2017-08-12]. Dostupný z www: < https://www.zakonyprolidi. $\mathrm{cz} / \mathrm{cs} / 2000-122>$.
}

a roku nabytí. ${ }^{23}$ Zde se přímo nabízí otázka, proč plýtvat lidskými zdroji, energií, časem a penězi na dublování způsobu evidence nálezů v postexkavační fázi výzkumu a nepřizpůsobit ji tezauračnímu postupu muzea, do kterého se nálezy budou předávat? Stačila by "pouze“ dohoda o součinnosti mezi muzeem a nesbírkotvornou institucí a ušetřila by se část práce muzejního pracovníka. ${ }^{24}$ Nejpozději do 3 let od zápisu do chronologické evidence má být provedena evidence druhého stupně, tzv. systematická, jež je oproti chronologické evidenci, která má charakter majetkoprávní a provádí se bezprostředně po zařazení sbírkového předmětu do sbírky, založená na odborném posouzení sbírkového předmětu (dopředu predikuje, o jakou sbírku jde). Inventární číslo tvoří zpravidla písmeno oboru, napr. $\mathrm{A}=$ archeologie, $\mathrm{k}=$ keramika + číslice). ${ }^{25}$

\section{Z výsledků dotazníkového šetření} v této otázce vyplývá, že nálezy jsou zpravidla častěji dokumentovány až po základním vyhodnocení terénní situace. Tento způsob preferují více sbírkotvorné instituce. Naopak nesbírkotvorné instituce více upřednostňují dokumentaci nálezů před základním vyhodnocením terénní situace ještě v terénu. Dokumentace probíhá průběžně od

\begin{tabular}{l}
\hline 23 Zde se uplatní tzv. hromadná evidence dle \\
$\S 2$, odst. 2 vyhlášky č. $275 / 2000$ Sb., každý \\
soubor archeologických nálezů z jednotlivých \\
archeologických výzkumů získá přírůstkové číslo \\
(podle chronologického zařazení do sbírky), které \\
se lomí rokem zařazení. Jedná se o fragmenty \\
keramických nádob z jednoho období či kontextu, \\
amorfní zlomky železných artefaktů, zvírýecí \\
kosti, mazanice, struska apod., které mohou mít \\
i v systematické evidenci jedno inventární číslo \\
(Česká republika. Vyhláška Ministerstva kultury \\
č. $96 / 2013$ Sb. ze dne 12 . dubna 2013 , kterou se \\
mění vyhláška č. $275 / 2000$ Sb., kterou se provádí \\
zákon č. $122 / 2000$ Sb., o ochraně sbírek muzejní \\
povahy a o změně některých dalších zákonů, \\
súčinností od 1. července 2013. In Sbírka zákonů \\
České republiky č. $96 / 2013$, částka 45, s. 1018- \\
1019 [online]. [cit. $2017-04-12$ ]. Dostupný z www: \\
$<$ http://aplikace.mvcr.cz/sbirka-zakonu/ViewFile. \\
aspx?type=z\&id=25854>.
\end{tabular}

24 Funkčnost toho postupu zatím potvrzuje jediný případ spolupráce.

25 Nemusí tomu tak být vždy, některá muzea používají tradičně průběžnou číselnou řadu bez písemného označení, jiná využívají kontextuálního číslování nálezů, př́ípadně se systémy kombinují. prvního zjištění nálezové situace, kdy je předmět ještě dokumentován in situ, a dále během zpracování (základního očištění, preventivní konzervace, příp. restaurování i následné prezentace). Kreslení a fotografování artefaktů, převážně vybraných předmětů, je preferováno v obou typech institucí, ale objevily se i další způsoby dokumentace, jako např́íklad skenování pomocí 3D skeneru a slovní popis artefaktů. Frotáž, kterou praktikují v Národním památkovém ústavu ú. o. p. v Praze, neprovádí nikdo $\mathrm{z}$ dotazovaných. ${ }^{26}$

\section{Depozitáře a obalové materiály}

Po provedení evidence, dokumentace, preventivní konzervace a v př́ipadě potřeby i restaurování předmětu dochází $\mathrm{k}$ další fázi tezauračního procesu, ukládání předmětu do depozitáře. Sbírkotvorné instituce mají tzv. muzejním zákonem 122/2000 Sb., danou povinnost pečovat o sbírkový fond v muzejním depozitáři, kde jsou předměty uloženy trvale, nesbírkotvorné instituce ukládají své nálezy přechodně do dočasných depozitář̀̊, v nichž zůstávají do doby, než budou na základě jiného, tzv. památkového zákona 20/1987 Sb., předány do sbírkotvorné instituce - muzea. $\mathrm{V}$ některých případech nálezy na trvalé uložení čekají i několik let. Pro depozitáře (přechodné či trvalé) platí zvláštní režim zakotvený v základní směrnici, depozitárním řádu, jeho vypracování je zákonnou povinností dotčených institucí. Depozitární řád jasně stanoví provozní podmínky depozitáře, určuje kompetence jednotlivých pracovníků pověřených vstupem do depozitáře a manipulací se sbírkovými předměty a pravidla přístupu do depozitáře. Nedílnou součástí

26 Odpovědi zahraničních respondentů nepřinesly žádný nový poznatek, užívají standardní kreslení a fotografování vybraných předmětů. Tuto činnost praktikují před (Francie) i po (Rakousko, Polsko) základním vyhodnocením terénní situace, anebo, jak je tomu v řecké nesbírkotvorné instituci, v obou př́padech. 
depozitárního řádu je i badatelský řád.

Depozitáře, at trvalé či přechodné musí splňovat standardy bezpečnosti a preventivní ochrany sbírek, tak, jak jsou primárně zakotveny v Úmluvě o ochraně archeologického dědictví Evropy, ${ }^{27}$ podle které se každá smluvní strana se zavazuje zaručit $\mathrm{v}$ rámci svého právního režimu fyzickou ochranu archeologického dědictví. $\mathrm{V}$ rámci České republiky je ochrana sbírkových předmětů garantována $\mathrm{v} \S 9$ zákona 122/2000 Sb., o ochraně sbírek muzejní povahy a o změně některých dalších zákonů. ${ }^{28}$ Režim ochrany sbírek muzejní povahy je dále rozpracován ve vyhlášce 275/2000 Sb., kterou se provádí zákon 122/2000 Sb., novelizované pod číslem 96/2013 Sb. ${ }^{29}$

Depozitáře se $\mathrm{z}$ převážné většiny nacházejí $\mathrm{v}$ prostorách původně určených $\mathrm{k}$ jinému účelu, než je uchovávání sbírkových předmětů, a proto je nezrrídka potřeba budovy přizpůsobit charakteru uložené sbírky. Dochází k přestavbám historických a užitkových budov, ale objevují se i stavby postavené tzv. na zelené louce. Zásady a doporučení pro plánování, samotnou výstavbu a vybavení depozitářů, režim ochrany a bezpečnosti sbírkového fondu a jeho preventivní konzervaci jsou rozpracovány $\mathrm{v}$ metodických pokynech, které vydává Metodické

\footnotetext{
27 Úmluva o ochraně archeologického dědictví Evropy (revidovaná). In Mezinárodní dokumenty o ochraně kulturního dědictví. 1. vyd. Praha: Národní památkový ústav, ústřední pracoviště, 2007, s. 160-173.

28 Česká republika. Zákon č. 122/2000 Sb. ze

dne 7. dubna 2000 o ochraně sbírek muzejní pova-

hy a o změně některých dalších zákonů, s platností a účinností od 12. 5. 2000. In Sbírka zákonů České republiky, částka 36 [online]. Aktuální znění 2017-07-01. [cit. 2017-08-12]. Dostupný z www: $<$ https://www.zakonyprolidi.cz/cs/2000-122>. 29 Česká republika. Vyhláška Ministerstva kultury č. 96/2013 Sb. ze dne 12 . dubna 2013, kterou se mění vyhláška č. 275/2000 Sb., kterou se provádí zákon č. 122/2000 Sb., o ochraně sbírek muzejní povahy a o změně některých dalších zákonů, s účinností od 1. července 2013. In Sbírka zákonu České republiky č. 96/2013, částka 45, s. 10181019 [online]. [cit. 2017-04-12]. Dostupný z www: $<$ http://aplikace.mvcr.cz/sbirka-zakonu/ViewFile. aspx? type $=z \& i d=25854>$.
}

centrum konzervace (dále MCK) Technického muzea v Brně. ${ }^{30}$

Trvalý depozitář mají dle předpokladu všechny sbírkotvorné instituce, u některých se nacházejí i depozitáře dočasné. Nesbírkotvorné instituce převážně ukládají archeologické nálezy do dočasných depozitářù, ale také jsou instituce, které vlastní trvalý depozitáŕ. Zahraniční respondenti, at náleží k typu sbírkotvorné či nesbírkotvorné instituce, mají depozitáŕ trvalý.

Metodické pokyny MCK doporučují mimo jiné i obalový materiál a techniku ukládání jednotlivých předmětů a dále podmínky prostředí pro jejich dlouhodobé ukládání $\mathrm{v}$ depozitářích. Vždy je třeba vytvářet monomateriálové depozitáře, $\mathrm{u}$ artefaktů vyrobených z kombinovaných materiálů jsou podmínky režimu nastaveny na upřednostnění citlivějš́ího z nich. Je nezbytné používat jen ty obalové materiály, které neobsahují organické kyseliny (octovou, mravenčí) a aldehydy. Pro uložení některých druhů předmětů jsou vhodnější nekyselé papírové obaly ( $\mathrm{Ph}$ neutrální, popř. $s$ alkalickou rezervou), archivní papíry, nebarvená bavlna, len apod. Z plastových nebarvených obalů jsou vhodné polystyren, polyethylen, polyethylen thereftalát, polyakryláty. K dalším použitelným obalovým materiálům patří např́íklad polyethylenové pěny.

\section{Téměř všichni dotazovaní balí} nálezy do sáčků z papíru a plastu a ukládají je do papírových krabic, necelá polovina respondentů pou-

\footnotetext{
30 SELUCKÁ, Alena, Ivo ŠTĚPÁNEK a Martin MRÁZEK. Obecná charakteristika muzejního depozitáře. Metodické pokyny, $3 \mathrm{~s}$. Metodické cent rum konzervace Technické muzeum v Brně [online]. [C TMB MCK, 2011]. [cit. 2017-09-18]. Dostupný z www: <http://prog-story.technicalmuseum.cz/ mck/images/stories/clanky/metodika/obecna_charakteristika_muzejniho_depozitare.pdf >; Doporučené podmínky prostředí pro dlouhodobé ukládání př̀edmětů v depozitářích. Metodické pokyny, 7 s. In Metodické centrum konzervace Technické muzeum v Brně [online]. [C TMB MCK, 2011]. [cit. 2017-09-18]. Dostupný z www: <http://mck.technicalmuseum.cz/images/stories/clanky/metodika/ doporucene_podminky_prostredi.pdf $>$
}

žívá krabice z plastu, odkyselený papír užívá minimum respondentů (konkrétně $8 \%$ ). Někteří z nich doplnili další typy obalového materiálu, například nopoplank, buničitou vatu, polystyrén či drobné papírové krabičky, anebo nechávají předměty bez obalového materiálu volně na regálech. Zahraniční respondenti volí jako obalový materiál krabice papírové, z odkyseleného papíru i plastové. Používají sáčky plastové, papírové a $\mathrm{z}$ dalších materiálů, např. látkové podle typu materiálu a předmětu. Také je používán měkký plast, jehož tvar se uzpi̊sobí skalpelem, aby předmět zapadl a nepohyboval se a následně se umístí do papírové nebo plastové krabice. Objemné nálezy (zásobní a transportní keramika, architektonické články apod.) se ukládají do dřevěných krabic vyráběných na míru každému artefaktu.

\section{Personální zastoupení a kvalifi- kace pracovníků}

Otázka týkající se personálního zastoupení v jednotlivých institucích byla spíše orientační, žádné neočekávané výsledky nepřinesla, kromě toho, že v nesbírkotvorných institucích pracuje více jak jednou tolik zaměstnanců.

Z uvedeného přehledu jednotlivých kategorií dosaženého vzdělání je patrné, že pro terénní kopáčské práce jsou pracovníci většinou zajištováni subdodavatelskými firmami. Zajímavý byl rozdíl ve spolupráci se subdodavatelskými firmami v Čechách a na Moravě. Zatímco v Čechách je poměr spolupracujících a nespolupracujících se subdodavateli téměř shodný, na Moravě velkou převahu získala záporná odpověd' - $88 \%$ institucí nespolupracuje se subdodavatelskými firmami. Jeden zástupce sbírkotvorné instituce svou zamítavou odpověd’ zdůvodňuje nedostatkem financí. Pro terénní práce i zpracování využívají více pracovníků na DPP či DPČ nesbírkotvorné instituce. Je to 
více méně logické, nesbírkotvorné instituce často fungují i jako subdodavatelé.

Z odpovědí zahraničních respondentů nebyly vyhodnoceny žádné překvapivé závěry. $O$ počtu zaměstnanců odpovídali neurčitě, s výjimkou Francie ostatní respondenti spolupracují se subdodavatelskými firmami či dočasně navyšují počet svých zaměstnanců.

\section{Dostupnost archeologických ná- lezů}

Prezentace sbírkových předmětů patří k hlavní náplni poslání muzea jako kulturně-vzdělávací, výchovné a pamětové instituce a je př́mo daná zákonem 122/2000 Sb. ${ }^{31}$ Zpřístupněním sbírek veřejnosti se dotýká také Profesní etický kodex ICOM pro muzea, a to $\mathrm{v}$ části 3, § 3.2 „Dostupnost sbírek“. ${ }^{32}$ O možnosti a způsobu zpřístupnění sbírkových předmětů pro účely bádání veřejnosti neboli „muzejních návštěvníků se zvláštními zájmy“, ve své práci referuje Friedrich Wai-

31 Tím, že muzeum „umožňuje způsobem zaručujícím rovný př́stup všem bez rozdílu jejich využívání a zpř́stupňování poskytováním vybraných veřejných služeb“ je naplněn obsah třetí a poslední teorie systému muzeologie nazvané teorie prezentace (předcházejí teorie selekce a teorie tezaurace). Veřejné služby podle muzejního zákona mají sloužit „k uspokojování kulturních, výchovných, vzdělávacích a informačních potreb veřejnosti“. Vybrané veřejné služby tuto činnost úžeji vymezují, nebot spočívají „ve zpřístupňování a yyužívání sbírek nebo jednotlivých sbírkových předmětů a poznatků o prrírodě a historii z nich získaných prostrednictvím muzejních výstav, muzejních programů, muzejních publikací a poskytování informací o př́rodě nebo společnosti, získaných studiem prírodnin nebo lidských výtvorů, sbírek a sbírkových předmětů nebo prostředí, z něhož jsou sbírkové předměty získávány.“ (Česká republika. Zákon č. 122/2000 Sb. ze dne 7. dubna 2000 o ochraně sbírek muzejní povahy a o změně některých dalších zákonů,

s platností a účinností od 12. 5. 2000, § 2, odst. 6 . In Sbírka zákonů České republiky, částka 36 [online]. Aktuální znění 2017-07-01. [cit. 2017-08-12]. Dostupný z www: < https://www.zakonyprolidi. $\mathrm{cz} / \mathrm{cs} / 2000-122>$ ).

32 „Muzea mají specifickou povinnost co nejvyšší možnou měrou volně zpř́stupnit své sbírky a všechny informace s nimi spojené, s výjimkou nutných omezení z důvodů utajení nebo bezpečnosti“. Cást 5 je sice nazvaná „Muzejní sbírky poskytují možnosti dalšího využití pro veřejnost", ale jakým zpo̊sobem se neuvádí (Profesní etický kodex ICOM pro muzea. Asociace muzeí a galerií České republiky, 2009 [online]. [cit. 2017-08-18]. Dostupný z www: $<$ http://www.cz-museums.cz/web/deni_v_oboru/ eticky-kodex-muzei $>$ ). dacher. Zmiňuje existenci veřejné studijní sbírky, která funguje jako muzejní věcný archiv pro vědecké a badatelské účely. Vyzdvihuje přitom nutnost dodržovat zásady preventivní ochrany sbírkových př̀edmětů. ${ }^{33}$

Badatelé pro své studijní záměry využívají nejen sbírkové předměty, ale též nálezové zprávy. Průzkumem bylo zjištěno, že více jak polovina $\mathrm{z}$ celkového počtu dotazovaných archivuje pouze vlastní nálezové zprávy. Jedná se převážně o nesbírkotvorné instituce. Sbírkotvorné instituce kromě vlastních nálezových zpráv uchovávají ve svém archivu i nálezové zprávy ostatních institucí pracujících $\mathrm{v}$ daném regionu, které jim byly předány současně $s$ materiálem z výzkumu. Zápůjčky nálezových zpráv podléhají interním předpisům instituce.

Badatel se musí nejprve seznámit $s$ badatelským řádem dané instituce a vyplnit badatelský list (nebo také Žádost badatele o studium), které jsou spolu s depozitárním a návštěvním řádem dalšími povinnými interními dokumenty. Převážná většina odpovídajících se shodla na volném neformálním postupu, kdy žadatel získá potřebné materiály na základě vyplněného badatelského listu a jeho evidence. Někdy je třeba souhlas autora výzkumu, např. pokud se jedná o dosud nepublikovaný výzkum bývalých zaměstnanců instituce. Další možností získání povolení přístupu k žádaným informacím je přes souhlas vedoucího pracovníka (ředitele) instituce na základě oficiální písemné žádosti. V jedné nesbírkotvorné instituci tuto situaci řeší neformálně dohodou. Důvodem je malý zájem ze strany badatelů.

V zahraničí se situace $s$ archivací nálezových zpráv různí podle místa

33 WAIDACHER, Friedrich. Príručka všeobecnej muzeológie. Bratislava: Slovenské národné muzeum, 1999, s. 154. i zaměření jednotlivých institucí. Např́klad v Řecku je považován za dostatečný výstup tzv. field report, který je volně dostupný. Přístup k nálezovým zprávám i uloženým předmětům umožňují badatelům pouze se souhlasem autora výzkumu (písemným či ústním) nebo se souhlasem vedoucího pracovníka (ředitele).

K novým trendům umožňujícím zpřístupnění sbírkových předmětů badatelům i široké veřejnosti patří postupná digitalizace sbírek. Muzejní pracovníci $\mathrm{k}$ tomuto počinu zprvu přistupovali s jistou nedůvěrou a obavami o osud muzeí, ale v současnosti se již jejich obavy pomalu rozptylují, nebot sebelepší snímek artefaktu nemůže nahradit přímý kontakt, atmosféru, kterou návštěvník „nasává“ při pohledu na autentického svědka události. $\mathrm{V}$ případě nedostupnosti sbírkových předmětů (z důvodu jejich velké vzdálenosti, výjimečnosti, atraktivity, špatného stavu nebo vlastní fyzické indispozice potenciálního návštěvníka) nalezne digitalizace široké uplatnění. Dalším nápadem, jak zpopularizovat archeologický sbírkový fond, je tzv. odtajnění depozitářů. Po vzoru ze zahraničí vzniká nová funkce depozitáře, tzv. Schaudepot - depozitář uzpưsobený pro občasné prohlídky pro veřejnost. Nově přestavěné a postavené depozitáře již počítají kromě badatelen i s konferenčními, výstavními a přednáškovými sály a učebnami pro objektové učení pro školy i širokou veřejnost. Samozřejmostí již dnes jsou bezbariérové př́ístupy.

\section{Sbírkové a nesbírkové instituce - spolupráce?}

Otázka týkající se vzájemné spolupráce sbírkotvorných a nesbírkotvorných institucí byla vyvolaná situací, která nastala přijetím novely č. 1/2005 Sb., zákona 20/1987 Sb., o státní památkové péči ve znění pozdějších změn, konkrétně $\S 23 a$ „Vlastnictví movitých archeologic- 
kých nálezů“ “. ${ }^{34}$ Tato problematika a její dopad na Národní památkový ústav je podrobněji rozpracovaná $\mathrm{v}$ autorčině bakalářské práci. ${ }^{35}$ Dotaz byl cílený primárně na zástupce nesbírkotvorných institucí, ovšem reakce pěti respondentů ze sbírkotvorných institucí poukázala na fakt, že tento zákon přináší zátěž i jim.

Ze součtu odpovědí vyplývá, že převážná většina nálezů $\mathrm{z}$ archeologických výzkumů prováděných nesbírkotvornými institucemi přechází do sbírek muzeí zřízených kraji či obcemi. Někteří respondenti předávají nálezy jak do institucí zřízených státem, tak i krajem či obcí, jiní spolupracují pouze s muzei zřízenými státem. Zkušenosti s interinstitucionální spoluprací byly u nesbírkotvorných institucí převážně negativní a hlavním důvodem byla neochota muzeí přijímat archeologické nálezy. Sbírkotvorné instituce tento fakt odůvodňují nedostatkem prostoru, kapacitní nedostatečností muzea, rekonstrukcí objektu, personálními změnami $\mathrm{v}$ instituci. $\mathrm{V}$ jednom případě bylo zjištěno, že muzeum archeologické nálezy téměř neodebírá, vyžaduje ovšem každoroční aktualizovaný seznam toho, co by mělo převzít. Muzea často stanovují striktní podmínky pro převzetí nálezů, jako například vypracovaná nálezová zpráva připojená $\mathrm{k}$ základní evidenci nálezů, anebo shodný způsob evidence a balení nálezů, jaký užívají sami. Což je na jednu stranu ekonomičtějšíi, $\mathrm{z}$ důvodu ušetření pracovních sil a nákladů muzea a některé nesbírkotvorné instituce na tuto dohodu bez problému při-

34 Česká republika. Zákon č. 20/1987 Sb. o státní památkové péči, ve znění pozdějších změn podle právního stavu [online]. [cit. 2017-06-26] Dostupný z www: < https://www.zakonyprolidi. $\mathrm{cz} / \mathrm{cs} / 1987-20>$

35 BLAŽKOVÁ, Ivana. Archeologické sbírky v památkové péči na př́kladu Národního památkového ústavu, územního odborného pracoviště v hlavním městě Praze. Brno: Masarykova univerzita, Filozofická fakulta Masarykovy univerzity, Ústav archeologie a muzeologie, 2015. 78 s. Bakalářská diplomová práce. Vedoucí práce PhDr. Irena Loskotová, Ph.D. stupují, ale jsou i tací, pro které je tento postup velkou finanční zátěží.

Z dalších odpovědí vyplývá, že některé nesbírkotvorné instituce zpracovaný nálezový fond ukládají do svých dočasných depozitářù a s muzei zatím nezahájily aktivní spolupráci. Naskytla se př́iležitost porovnat tři odpovědi z jedné instituce, ale z různých pracovišt', která mají pravděpodobně rozdílné podmínky (dvě odevzdávají do muzeí zřízených krajem nebo obcí, třetí do muzea zřízeného státem), jejich zkušenosti se součinností s muzeem se diametrálně lišily. Respondenti ze sbírkotvorných institucí ve dvou prrípadech kladně ohodnotili spolupráci se svými kolegy z nesbírkotvorných institucí, jedna odpověd' byla negativní - muzeum by rádo spolupracovalo, avšak ze strany nesbírkotvorné instituce nebyl zájem.

Ze zahraničních respondentů byla otázka cílena pouze na dvě nesbírkotvorné instituce. Francouzský zástupce hodnotil spolupráci jako výbornou. Řecká strana komentovala problém šířeji, součinnost označila za problematickou. Povinnost zajistit uložení v podmínkách splňujících literu zákona je přenesena na jednotlivé výzkumné expedice.

\section{Zhodnocení a závěry}

Po celkovém vyhodnocení výsledků všech odpovědí lze říci, že úroveň nakládání s archeologickými nálezy není špatná. Hlavní roli hrají finance. Dalším důvodem je uzavřenost oborů, nedostatečná snaha komunikovat mezi institucemi, předávat si své zkušenosti a informovat o nových trendech, např. v preventivní konzervaci. Nové poznatky na konferencích nejsou hromadněji rozšiřovány, pokud se někdo neúčastní konference přímo, mnohdy nemá možnost přístupu k informacím, které zde zazněly, nebot' výstupy z konferencí nejsou publikovány $\mathrm{v}$ plném rozsahu a tvoří je pouze několik příspěvků v odborném časopise.

Absence jakéhokoliv metodického centra je př́činou toho, co vyplývá $\mathrm{z}$ reakcí archeologů mimo sbírkotvorné instituce. Je patrná určitá nejasnost v chápání mezioborové problematiky, a to i např́íklad ve výkladu zdánlivě obsahově jasných termínů jako jsou konzervace a restaurování nálezu. Z ojedinělých odpovědí by bez dalšího rozboru a čistě z muzeologického hlediska vyplynulo, že je standardem odevzdat nálezy v podobě, jak byly vyjmuty ze země. Metodické centrum, tak jako v jiných specifických oborech (jako např. Metodické centrum konzervace Technického muzea v Brně), by garantovalo zapojení obou typů institucí do vzájemné komunikace, oborového propojení a pochopení problematiky.

Z dotazníkového šetření vyplynula nejednotnost $\mathrm{v}$ postupech vedoucí $\mathrm{k}$ muzealizaci nálezů, a to i $\mathrm{v}$ rámci jedné instituce. Vždy záleží na samotném archeologovi, jak věc posoudí, což může být $\mathrm{k}$ prospěchu, ale i $k$ velké škodě věci, především v otázkách selekce a tezaurace. Ke korigování tohoto individuálního přístupu by mělo přispět primární studium archeologie i další odborné vzdělávání.

Odpovědi zahraničních respondentů jsou kvůli nízké četnosti pouze ilustrativní a mohou inspirovat naše instituce snad jen $\mathrm{v}$ případě rozmanitosti obalového materiálu.

Závěrem lze formulovat několik obecných doporučení:

- Do budoucna zřídit v rámci České republiky metodické centrum speciální muzeologie a zformulovat etický kodex archeologa.

- Prozatím alespoň v rámci institucí sjednotit interní prredpisy k procesu muzealizace předmětu. 
- Ve fázi evidence a uložení předmětů nevzdávat pokusy o navázání užší spolupráce mezi institucí nesbírkotvornou a sbírkotvornou. Výsledkem bude jasná úspora finančních i lidských zdrojů, což dokazuje prozatím bohužel ojedinělý prríklad dobré praxe.

- I dočasné uložení předmětů musí být $\mathrm{v}$ souladu s patřičnou legislativou. Není možné poukazovat na neúnosné ekonomické zatížení. I nesbírkotvorné instituce musí být připravené nést tyto náklady. Většina movitých archeologických nálezů pochází ze záchranných archeologických výzkumů, ty jsou převážně hrazeny druhou stranou (i v prrípadě tzv. neinvestorských akcí mohou být náklady kompenzovány z programu podpory záchranných archeologických výzkumů). Preventivní konzervace nálezů je nedílnou součástí výzkumu a při tvorbě rozpočtu musí být $\mathrm{s}$ touto položkou počítáno.

- Každá instituce je povinna mít vypracovaný badatelský ráa a pro badatele připravený badatelský list. Nelze se odvolávat na nízký zájem výzkumníků a poskytování např̀. nálezových zpráv řešit neformální dohodou, mohlo by zde dojít i k porušení autorských práv.

- Zatím vzácná shoda mezi pracovníky obou typů institucí panuje $\mathrm{v}$ nespokojenosti se současnou legislativou. V zájmu zachování kulturního dědictví je třeba apelovat na profesní čest, a i přes případné osobní neshody vést dialog a snažit se dojít konsensu a zákonodárcům nabídnout jednotnou koncepci řešení situace.

\section{SEZNAM POUŽITÝCH ZDROJŮ A LITERATURY}

Česká republika. Zákon č. 20/1987 Sb., o státní památkové péči, ve znění pozdějších změn obsažených v zákonech č. 242/1992 Sb., č. 361/1999
Sb. a č. $61 / 2001$ Sb., č. $122 / 2000$ Sb., č. 132/2000 Sb., č. 146/2001 Sb., č. 320/2002 Sb., č. 18/2004 Sb., č. 186/2004 Sb., č. 1/2005 Sb., č. 3/2005 Sb., nálezu Ústavního soudu ČR č. 240/2005 Sb., zákona č. 186/2006 Sb., zákona č. 203/2006 Sb., zákona č. 158/2007 Sb., zákona č. 124/2008 Sb., zákona č. 189/2008 Sb., zákona č. 307/2008 Sb., zákona č. 223/2009 Sb., zákona č. 227/2009 Sb., zákona č. 124/2011 Sb., zákona č. 142/2012 Sb. a zákona č. 303/2013 Sb. podle právního stavu s účinností od 1. ledna 1988. In Sbírka zákonů České republiky, částka 6 [online]. Aktuální znění 2017-07-01 až 2017-12-31. [cit. 2017-06-26]. Dostupný z www: <https://www.zakonyprolidi. $\mathrm{cz} / \mathrm{cs} / 1987-20>$.

Česká republika. Zákon č. 122/2000 Sb. ze dne 7. dubna 2000 o ochraně sbírek muzejní povahy a o změně některých dalších zákonů, s platností a účinností od 12. 5. 2000. In Sbírka zákonů České republiky, částka 36 [online]. Aktuální znění 2017-07-01. [cit. 2017-08-12].

Dostupný z www: <https://www.zakonyprolidi.cz/cs/2000-122>.

Česká republika. Vyhláška Ministerstva kultury č. 96/2013 Sb. ze dne 12. dubna 2013, kterou se mění vyhláška č. 275/2000 Sb., kterou se provádí zákon č. 122/2000 Sb., o ochraně sbírek muzejní povahy a o změně některých dalších zákonů, s účinností od 1. července 2013. In Sbírka zákonů České republiky č. 96/2013, částka 45, s. 1018-1019 [online]. [cit. 2017-04-12]. Dostupný z www: < http://aplikace.mvcr. cz/sbirka-zakonu/ViewFile.aspx?ty$\mathrm{pe}=\mathrm{z} \& \mathrm{id}=25854>$.

Doporučené podmínky prostředí pro dlouhodobé ukládání předmětů v depozitářích. Metodické pokyny, 7 s. In Metodické centrum konzervace Technické muzeum v Brně [online]. [C TMB MCK, 2011]. [cit. 2017-09-18]. Dostupný z www: $<$ http://mck.technicalmuseum.cz/images/stories/clanky/metodika/doporucene_podminky_prostredi.pdf $>$.

Profesní etický kodex ICOM pro muzea. Asociace muzeí a galerií České republiky [online]. [cit. 2017-08-18]. Dostupný z www: <http://www.cz-museums.cz/ web/deni_v_oboru/eticky-kodex-muzei $>$.
Pokyny ke zhotovení nálezové zprávy. Archeologický ústav AV ČR, Praha [online]. [aktualizováno 2015-04-12]. [cit. 201709-18]. Dostupný z www: <http://www. aruo.cas.cz $/$ ?cat $=647>$.

BENEŠ, Josef. Muzeum a sbírky. Praha: Ústav pro informace a řízení v kultuře, 1977. $330 \mathrm{~s}$.

BENEŠ, Josef. Základy muzeologie. 1. vyd. Opava: Open Education\&Sciencies, 1997. 179 s. ISBN 80-901974-4.

BLAŽKOVÁ, Ivana. Od archeologického nálezu ke sbírkovému předmětu: průzkum péče o archeologické nálezy ve sbírkotvorných i nesbírkotvorných institucích $v$ České republice a v sousedních státech. Brno: Masarykova univerzita, Filozofická fakulta Masarykovy univerzity, Ústav archeologie a muzeologie, 2017. Magisterská diplomová práce. 129 s. Vedoucí práce PhDr. Irena Loskotová, Ph.D.

BLAŽKOVÁ, Ivana. Archeologické sbírky $v$ památkové péči na př́kladu Národního památkového ústavu, územního odborného pracoviště v hlavním městě Praze. Brno: Masarykova univerzita, Filozofická fakulta Masarykovy univerzity, Ústav archeologie a muzeologie, 2015. 78 s. Bakalářská diplomová práce. Vedoucí práce PhDr. Irena Loskotová, Ph.D.

CÍR, Dimitrij. Teorie muzejní selekce. Brno: Masarykova univerzita, Filozofická fakulta Masarykovy univerzity, Ústav archeologie a muzeologie, 2006. $72 \mathrm{~s}$. Diplomová práce. Vedoucí práce Mgr. Pavel Holman.

DOLÁK, Jan. K teorii sbírkotvorné činnosti muzeí: některé problémy muzejní selekce. In Teorie a praxe vybraných muzejních činností. 1. vyd. Brno: Technické muzeum v Brně, 2005, s. 4-11. ISBN 80-86413-20-9.

HOLMAN, Pavel. Úvod do muzeologie. In Základy muzejní pedagogiky: studijní texty. Brno: Moravské zemské muzeum Brno, 2014, s. 11-23. ISBN 978-80-7028-441-4.

KRUŠINOVÁ, Lenka a Jiří VARHANÍK. Archeologické výzkumy a nálezy: výukový materiál k predmětu AEB_34 Právní rámec záchranného archeologického výzkumu. Brno: Ústav archeologie a muzeologie Masarykovy univerzity [online]. [cit. 2017-09-14]. Dostupný z www: $<$ https://is.muni.cz/el/1421/ 
podzim2013/AEB_34/Cast_III. zak.c.20-1987_Sb.doc>.

NEUSTUPNÝ, Evžen. Metoda archeologie. Plzeň: Vydavatelství a nakladatelství Aleš Čeněk, 2007. 206 s. ISBN 978-80-7380-075-8.

NEUSTUPNÝ, Evžen. Vymezení archeologie. In Archeologie pravěkých Čech/1: pravěký svět a jeho poznání. Praha: Archeologický ústav AV ČR, Praha, 2007, s. 11-22. ISBN 978-80-86124-75-9.

NEUSTUPNÝ, Jiří. Otázky dnešního musejnictví: př́spěvky $k$ obecné a speciální museologii. Praha: Orbis, 1950. 207 s.

NEUSTUPNÝ, Jiří. Muzeum a věda. Praha: Kabinet muzejní a vlastivědné práce při Národním muzeu v Praze, 1968. $168 \mathrm{~s}$. RUTAR, Václav. Geneze pojmů muzeálie, muzealita a muzealizace na stránkách Muzeologických sešitů v letech 19691986 [online]. Museologica Brunensia, 2012, roč. 1, č. 1 (Podzim 2012), s. 6-13 [cit. 2017-06-06]. Dostupný z www: $<$ http://hdl.handle.net/11222.digilib/131349>.
SELUCKÁ, Alena, Ivo ŠTĚPÁNEK a Martin MRÁZEK. Obecná charakteristika muzejního depozitáře. Metodické pokyny, $3 \mathrm{~s}$. Metodické centrum konzervace Technické muzeum v Brně [online]. [@ TMB MCK, 2011]. [cit. 2017-09-18]. Dostupný z www: <http:// prog-story.technicalmuseum.cz/mck/ images/stories/clanky/metodika/obecna_ charakteristika_muzejniho_depozitare. pdf $>$.

SCHUBERTOVÁ, Věra. K aktuálním otázkám teorie muzejní selekce. Muzeologické sešity, 1979, 7, s. 30-45.

STRÁNSKÝ, Zbyněk Zbyslav. Úvod do studia muzeologie. 2. rozšír. vyd. Brno: Masarykova univerzita, 2000. $169 \mathrm{~s}$. ISBN 80-210-1272-2.

STRÁNSKÝ, Zbyněk Zbyslav. Archeologie a muzeologie. 1. vyd. Brno: Masarykova univerzita, 2005. $315 \mathrm{~s}$. ISBN 80-210-3861-6.

WAIDACHER, Friedrich. Príručka všeobecnej muzeológie. Bratislava: Slovenské národné muzeum, 1999. $477 \mathrm{~s}$. ISBN 80-8060-015-5.

\section{IVANA BLAŽKOVÁ}

\section{Městská knihovna v Praze,}

Praha, Česká republika

ivana.blazkova@mlp.cz

Externí spolupracovnice Archeologického oddělení Národního památkového ústavu, územního odborného pracoviště v Praze. Absolventka oboru muzeologie na Filozofické fakultě Masarykovy univerzity v roce 2018.

External collaborator in the Archaeological Department of the National Heritage Institute, Regional Office in Prague. Graduated in the field of museology at the Faculty of Arts, Masaryk University in 2018. 